\title{
Staff Operational Guidelines On Dissemination Of Technical Assistance Information
}




\section{STAFF OPERATIONAL GUIDELINES ON DISSEMINATION OF TECHNICAL ASSISTANCE INFORMATION}

IMF staff regularly produces papers proposing new IMF policies, exploring options for reform, or reviewing existing IMF policies and operations. The Report prepared by IMF staff and completed on March 18, 2020, has been released.

The staff report was issued to the Executive Board for information. The report was prepared by IMF staff. The views expressed in this paper are those of the IMF staff and do not necessarily represent the views of the IMF's Executive Board.

The IMF's transparency policy allows for the deletion of market-sensitive information and premature disclosure of the authorities' policy intentions in published staff reports and other documents.

Electronic copies of IMF Policy Papers are available to the public from http://www.imf.org/external/pp/ppindex.aspx

\section{International Monetary Fund Washington, D.C.}




\title{
INTERNATIONAL MONETARY FUND
}

\section{STAFF OPERATIONAL GUIDELINES ON THE}

March 18, 2020

\author{
DISSEMINATION OF TECHNICAL ASSISTANCE
}

INFORMATION

\section{EXECUTIVE SUMMARY}

The Staff Operational Guidelines on Dissemination of Technical Assistance Information have been updated to reflect the authority reserved to Fund management and TA recipients to provide explicit consent for the dissemination of TA information in scenarios not specifically envisaged in these guidelines. 


\section{Approved By} Sharmini Coorey and

Rhoda Weeks-Brown
Prepared by Staff from the Legal Department and Institute for Capacity Development, in consultation with other departments

\section{CONTENTS}

I. INTRODUCTION

II. SCOPE OF THE OPERATIONAL GUIDELINES______ $\underline{4}$

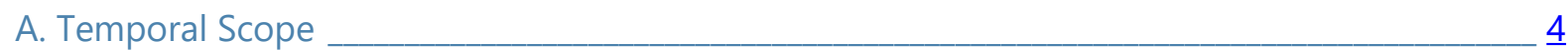

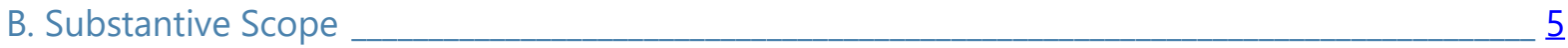

III. PROCEDURES GOVERNING DISSEMINATION OF TA INFORMATION ____ _ $\mathbf{7}$

A. Information Related to the Fact of TA Provision and Subject-Matter of TA____ $\underline{7}$

B. Information Related to the Administration of TA Projects_____

C. Information Forming the Basis of TA Advice______ $\underline{8}$

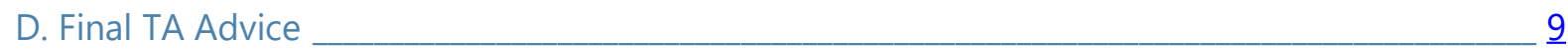

IV. SPECIFIC PROCEDURES FOR DISSEMINATION OF FINAL TA ADVICE ___ 1

A. Dissemination of Final TA Advice within the Fund _______

B. Dissemination of Final TA Advice, Including TA Reports, Outside the Fund ____ 12

V. IMPLEMENTATION OF THE GUIDELINES_______ $\mathbf{1 6}$

A. General Issues _______ 16

B. Reference to Guidelines Upon Requests for TA __________ 16

C. Categorization of TA Information and Recipients of TA Information _______ 17

D. Coming into Force of Guidelines________ 17

\section{APPENDICES}

Appendix A: Model Transmittal Letter _____ 18

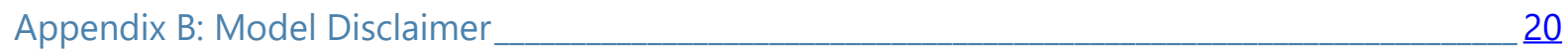

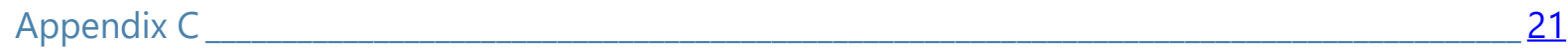

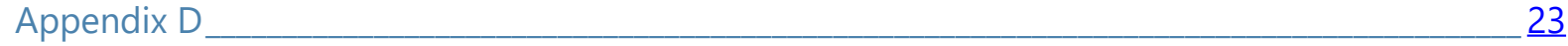




\section{INTRODUCTION}

TA information should be disseminated more widely. The more active sharing of TA information with donors and other TA providers will improve coordination, exploit synergies, and enable the Fund to prioritize and leverage its limited TA resources, thereby fulfilling key objectives under the Paris Declaration on Aid Effectiveness. Moreover, especially from the perspective of their own accountability to their governments and legislators, donors to the Fund's TA program have a legitimate interest in receiving information on TA that is financed by them. For TA recipient countries, the wider dissemination of TA information among different government agencies will strengthen ownership and facilitate the more effective implementation of TA recommendations. More generally, through publication, the membership and the public at large will benefit from a better understanding of best practices, and the Fund's experiences in the provision of TA.

\section{New Guidelines on Dissemination of TA Information: Where to Find What?}

The notes lay out:

$\rightarrow$ Which TA information falls under the new procedures (15), which information is not covered by these procedures ( $(16-7)$ and which different types of information should be distinguished (โ5).

$\rightarrow$ How to treat different types of information (18-12):

- Related to the fact of TA provision and subject matter of TA.

- Related to the administration of TA projects

- Forming the basis of TA advice

- Final TA advice.

$\rightarrow$ How to disseminate final TA advice to:

- Fund staff (\$13)

- Executive Directors' offices (\$14)

- Outside the Fund (₫15), including for the World Bank (\$17), donors and TA providers other than the World Bank ( $₫ 156$, and the general public ( $₫ 18)$

$\rightarrow$ How to implement the new procedures, including the role of departments (119-21), the role of staff ( $(\pi 22-24)$ and communication of the guidelines to the public ( $(125)$. 
1. In “Dissemination of Technical Assistance Information", management set out a framework for streamlined and strengthened procedures for the wider dissemination of technical assistance-related information ("TA Information", as defined in these guidelines) and stated its intention to issue guidelines to the staff setting forth the new procedures. ${ }^{1}$ Directors took note of management's intention to establish the new procedures and agreed with the objectives underpinning the call for wider dissemination, i.e., to facilitate more systematic and effective dissemination of TA Information including through encouraging publication, while safeguarding confidential information and the candidness of Fund advice. Directors further supported the planned publication of the guidelines containing the new procedures. ${ }^{2}$

2. As was noted in "Dissemination of Technical Assistance Information", in several circumstances, the consent of the TA recipient for dissemination of certain types of TA Information will be deemed granted unless the TA recipient explicitly objects to such dissemination. In this regard, as further elaborated below, these guidelines place potential TA recipients on notice that, in requesting Fund TA they will be deemed to have consented to the dissemination of certain types of TA information, unless they explicitly object. To provide such notice, the Fund will take a number of measures described below, including publication of the guidelines and their notification to members and other potential TA recipients. It should be noted, however, that except for those cases in which an ex-ante irrevocable consent may be required for externally-financed TA (see paragraph 16, last bullet below), once the consent to disseminate has been granted, implicitly or explicitly, such consent may be withdrawn by the TA recipient or a third party that provided confidential information to Fund staff any time prior to actual dissemination of the information in question.

3. In accordance with the foregoing, operational guidelines for the staff are set forth below. For ease of reference, a summary of the new procedures is presented in the Attachment.

\section{SCOPE OF THE OPERATIONAL GUIDELINES}

\section{A. Temporal Scope}

4. The new procedures set forth in these guidelines will apply only to TA information concerning TA projects approved on or after the effective date of May 1, 2009 established in paragraph 25 below.

\footnotetext{
${ }^{1}$ Dissemination of Technical Assistance Information; IMF; April 3, 2008.

2 Enhancing the Impact of IMF Technical Assistance; IMF; May 20, 2008.
} 


\section{B. Substantive Scope}

\section{The guidelines apply to the dissemination within and outside the Fund of all TA Information (excluding the ones covered under paragraphs 6 and 7). In particular:}

\section{- The following non-exhaustive categories of TA information are subject to the guidelines:}

(a) The fact of the provision of TA and the subject matter of TA;

(b) Information on the administration of TA projects (such as details regarding the project framework, monitoring and evaluation, budget figures, funding source, and timing of missions);

(c) Information, received or generated by Fund staff, that forms the basis of Fund TA advice. For purposes of the guidelines the term "information forming the basis of TA advice" includes not only information received by Fund staff from the TA recipient or third parties that is used as a basis for staff's analysis, but also all information produced or generated by Fund staff in the process of providing TA to a TA recipient, including drafts of the TA advice prepared by Fund staff before final TA advice is provided (see paragraph 5(d) below);

(d) Final TA advice. For purposes of the guidelines "final TA advice" means the output of the TA provided by Fund staff at the request of a TA recipient once it is in the final form under which it will be delivered by the Fund staff to the TA recipient. This category consists of final TA advice conveyed by Fund staff to the recipient of TA in the form of TA reports, other final documents such as finalized draft legislation or final aide-mémoires, e-mails, or orally.

- The guidelines will apply to the dissemination of TA information to the following nonexhaustive list of recipients:

(a) the TA recipient and other agencies or instrumentalities within the member country, non-member or international agency to which Fund TA is provided. For purposes of the guidelines, the term "TA recipient" means the governmental or intergovernmental agency or instrumentality that is the direct recipient of Fund TA within member countries, nonmembers and international agencies. Non-members and international agencies are included in this definition since, under Rule N-16(d) of the Fund's Rules and Regulations, the Fund may provide TA to them upon the prior approval of the Executive Board;

(b) Executive Directors and members of their staff;

(c) donors and other TA providers. For purposes of the guidelines the term "donor" includes any official bilateral or multilateral agency or instrumentality of the public 
sector that provides grants or concessional financing for TA. The term donor also includes parties other than the TA recipient and donors to a specific TA project who are members of Steering Committees, such as for regional technical assistance centers or topical trust funds funded through multi-donor subaccounts. Also, the term "other TA provider" means any official bilateral or multilateral agency or instrumentality of the public sector that provides TA;

(d) Fund staff; and

(e) the general public.

\section{The guidelines do not apply to the following types of TA-related information:}

(a) FSAP Reports. The guidelines do not apply to the dissemination of information derived from the Financial Sector Assessment Program (FSAP), a form of technical assistance, since the handling of such information is subject to a separate regime reflecting understandings reached between the managements of the Fund and the World Bank. ${ }^{3}$ More information on this regime for FSAP reports is available in the Guidance Note on the Fund's Transparency Policy. ${ }^{4}$

(b) ROSCs. The guidelines do not apply to the dissemination of these reports since the Executive Board has decided that, as documents circulated to the Board, the dissemination of these reports shall be governed by the Transparency Policy Decision. ${ }^{5}$

(c) Safeguards Assessment Reports. In certain contexts, safeguards assessments conducted by the staff constitute the provision of technical assistance. However, these guidelines do not apply to the dissemination of safeguards reports, which are subject to a separate disclosure regime under the safeguards assessment policy.

\section{The guidelines do not apply to dissemination of TA information that is governed by} the Board-established transmittal and open archives policies.

- Transmittal Policy. The transmittal policy governs the routine transmittal (i.e., on a regular basis) of certain types of reports (including TA reports) to certain international agencies that

\footnotetext{
${ }^{3}$ See Confidentiality Protocol-Protection of Sensitive Information in the Financial Sector Assessment Program

${ }^{4}$ See Guidance Note on the IMF's Transparency Policy; IMF; March 12, 2010, as amended, pages 9 (Box 2. Publication of FSAP-related Documents) and 34 (Appendix V).

${ }^{5}$ Review of the IMF's Transparency Policy; IMF; October 5, 2005, as amended.
} 
meet specified criteria (i.e., commonality of operational interests, reciprocal transmittal of comparable documents to the Fund, and confidentiality safeguards). ${ }^{6}$

- Open Archives Policy. TA reports over 20 years old are available to outside persons upon request, provided that reports originally classified "Strictly Confidential" may not be released if the Managing Director finds that the material remains highly confidential or sensitive. ${ }^{7}$

\section{PROCEDURES GOVERNING DISSEMINATION OF TA INFORMATION}

8. The principle underlying the dissemination of TA information is that dissemination requires the consent of both Fund management and the TA recipient. With respect to consent from Fund management, this authority has generally been delegated to the head of the authoring TA department. With respect to consent from the TA recipient, in some instances, this consent may be obtained on a non-objection basis or may be assumed given the subject of the information. This section lays out specific rules for each type of TA information. Further, in line with the above principle, in scenarios not specifically envisaged in these guidelines, such as dissemination short of publication to private-sector parties, dissemination may be authorized to specific parties with the explicit consent of the TA recipient and the approval of Fund management. ${ }^{8}$ The dissemination of confidential information may only take place with the explicit commitment of the recipients that such information shall be kept confidential. ${ }^{9}$ Where information has been received from a third party, the explicit consent of such party will also be required prior to the dissemination of the relevant information.

\section{A. Information Related to the Fact of TA Provision and Subject-Matter of TA}

9. The fact of provision of Fund TA in response to a particular TA request and the general subject matter of that TA is not considered confidential information, unless the TA recipient specifically indicates otherwise at the time of the request for TA.

\footnotetext{
${ }^{6}$ The Transmittal Policy (see Exchange of Documents with other International Agencies; IMF; February 11, 1993, as amended) has rarely been used for routine transmission of TA reports because, unlike use of Fund resources (UFR) and Article IV consultation reports, TA reports are not produced on a regular basis. In addition, some TA providers and donors may not qualify as "international agencies" within the meaning of the policy, and the criterion on commonality of operational interest may be difficult to meet.

${ }^{7}$ See Review of the Fund's' Transparency Policy-Archives Policy; IMF; December 17, 2009, as amended.

${ }^{8}$ In determining whether to provide consent to dissemination of TA information in a scenario not explicitly envisaged in these guidelines, management should take into account, inter alia, the impact of disclosure on the TA project, whether disclosure presents any reputational risks for the Fund, and whether disclosure furthers the underlying objectives of the TA being provided.

${ }^{9}$ Please consult with LEG and ICD for the language to be used for this commitment.
} 
- Information in this category would thus ordinarily be made available to Executive Directors in staff reports. In addition, and upon request, ${ }^{10}$ this type of information may be made available to TA providers and donors. The information may also be made available to the general public.

- In those cases, expected to be rare, where the TA recipient explicitly advises Fund staff that it does not want such information to be made available, particularly to the general public, the TA recipient's wishes shall be respected.

\section{B. Information Related to the Administration of TA Projects}

\section{Information dealing with the administration of a TA project is not considered} confidential, unless the TA recipient specifically indicates otherwise at the time of the request for TA.

- Since this type of information is not considered confidential unless so specified, it may be shared with Executive Directors and members of their staff upon their request. In any event, the results of TA evaluations will continue to be reported to Executive Directors on an annual basis under the Fund's TA Evaluation Program.

- In particular, given the high demand for this information and its importance for coordination among donors, this information would be made readily available to other TA providers and donors upon their request. This information may also be made available to the general public.

- However, Fund staff would not disclose information about third parties (i.e., parties other than the TA recipient and the Fund), including donors who are funding TA projects, that such third parties would normally regard as confidential (e.g., information on the terms of employment of a TA expert).

\section{Information Forming the Basis of TA Advice}

\section{Information provided to Fund staff by a TA recipient or a third party, or that is} generated by Fund staff in the context of the provision of TA, constitutes information that forms the basis of TA advice.

- Within this category there are two different types of information:

(a) Information provided by the TA recipient or third parties in the context of the provision of Fund TA; and

(b) Information generated by Fund staff in the course of provision of TA before the TA advice is finalized.

\footnotetext{
${ }^{10} \mathrm{~A}$ request, as defined in this document, can be made orally, in writing, or by electronic means, i.e., a click on a secured website of the Fund.
} 
- Information forming the basis of TA advice is presumed confidential and shall only be made available beyond Fund staff, management and the TA recipient in certain circumstances where such sharing is considered necessary to facilitate coordination with donors and other TA providers and to exploit synergies.

- Specifically, the head of the authoring TA department in consultation with the relevant area department may consent to the dissemination of the information referred to in (a) and (b) above, upon request of World Bank staff, donors or other TA providers with legitimate interest, when the TA recipient has also explicitly consented to such dissemination. Where information has been received from a third party, the explicit consent of such party will also be required prior to the dissemination of the relevant information.

- In determining whether to consent to the dissemination of information referred to in (a) and (b) above, the head of the authoring TA department in consultation with the relevant area department will take into account the following considerations:

$>$ The likelihood that the sharing of such information outside of staff, management and the TA recipient could undermine the Fund's ability to obtain all necessary data and information from country authorities and third parties.

$>$ The impact that the disclosure of such information might have on the candor of discussions during a TA project's execution, whether they be in the form of exchanges with country authorities and third parties or internal deliberations among Fund staff.

- This information will generally not be published.

\section{Final TA Advice}

\section{Final TA advice is considered confidential information and its dissemination requires} the consent of the TA recipient. Final TA advice may take the form of: (i) TA reports ${ }^{11}$, (ii) other documents containing finalized Fund staff advice including draft legislation or final aide-mémoires prepared by Fund staff, and (iii) final advice provided by Fund staff to a TA recipient through emails or orally.

- Staff should note that, except for cases where ex-ante irrevocable consent may be required for externally financed TA in accordance with paragraph 16 below, TA recipients may withdraw their consent to disseminate any time prior to actual dissemination of final TA advice.

\footnotetext{
${ }^{11}$ In Dissemination of Technical Assistance Information; IMF; April 3, 2008 (paragraph 17) staff used the term "TA reports" to cover all final TA advice, irrespective of whether such advice was technically a TA report. However, operationally, it would be impractical to treat the dissemination of emails and oral TA advice, for example, in the same way that TA reports are treated. For these reasons, the guidelines distinguish between "TA reports" and "other types of final TA advice".
} 
- Since "TA reports" are the main form of delivering final TA advice to TA recipients, Section IV below describes specific procedures for the dissemination of TA reports within and outside the Fund. All TA reports shall include a disclaimer summarizing the Fund's policy for dissemination of this type of information according to the guidelines as set forth in Appendix B.

- Specific rules for the dissemination of final TA advice other than TA reports are also outlined in Section IV below.

\section{SPECIFIC PROCEDURES FOR DISSEMINATION OF FINAL TA ADVICE}

\section{A. Dissemination of Final TA Advice within the Fund}

\section{Dissemination of final TA advice to Fund staff is governed by the following procedures:}

(a) Specific Rules for Dissemination of TA reports to Fund staff:

> Authoring TA departments are required to ensure that all finalized TA reports, except those classified as "STRICTLY CONFIDENTIAL"12 and FSAP reports, are forwarded to the Institutional Repository.

$>$ Of the TA reports that are forwarded to the Institutional Repository, those that are classified "FOR OFFICIAL USE ONLY" are accessible to all staff, while TA reports classified "CONFIDENTIAL" are accessible to a smaller group of staff, as determined in GAO No. 35, Rev. 2 (i.e., access on a need to know basis). The authoring TA department is responsible for making determinations on what constitutes need to know on a case-by-case basis. In making this determination the authoring TA department should take into account the express or implied understandings reached with the TA recipient, as well as the surrounding circumstances, including the nature of the information contained in the TA report.

\footnotetext{
12 Dissemination of TA reports that are classified as "STRICTLY CONFIDENTIAL" shall follow the rules set forth in General Administrative Order (GAO) No. 35, Rev. 2 ("Information Security_Policies Regarding Classified Documents of November 1, 2007) for dissemination within the Fund, and the Fund's Open Archives Policy for sharing outside the Fund. According to GAO No. 35, Rev. 2, access to a TA report classified as "STRICTLY CONFIDENTIAL" shall be limited to addressees who meet the "strict need to know criterion". Outside the Fund, persons may have access to "STRICTLY CONFIDENTIAL" documents under the Open Archives Policy upon their request, if the documents are over 20 years old, provided, however, that access to those documents will be granted only upon the Managing Director's consent to declassification (see Decision No. 14498-(09/126), as amended. Pursuant to GAO No. 35, Rev. 2, the Managing Director has delegated her authority on declassification under the Open Archives Policy to heads of departments. The Managing Director, with the consent of the TA recipient, may also approve the sharing of TA reports classified as "STRICTLY CONFIDENTIAL" outside the Fund prior to the 20-year period. In these cases, such sharing will take place only if understandings are reached between Fund staff and the outside recipient of the information that such information shall be treated by the latter as strictly confidential.
} 
$>$ TA reports classified as "CONFIDENTIAL" are reclassified automatically "FOR OFFICIAL USE ONLY" after two years, unless the authoring TA department or the relevant area department considers that the sensitivity of the information has not sufficiently diminished.

(b) Dissemination of other types of final TA advice to Fund staff:

Any form of final TA advice may be disseminated to Fund staff in accordance with the classification of the document and the procedures set forth in GAO No. 35, Rev.

\section{Dissemination of final TA advice to Executive Directors and members of their staff is governed by the following procedures:}

(a) Dissemination of TA reports to Executive Directors and members of their staff:

$>$ The general practice of making TA reports available to the Executive Director for the country of the TA recipient, unless the latter specifically requests otherwise, will continue to apply.

With respect to other Executive Directors and members of their staff, access to TA reports requires the consent of the TA recipient. Consent will be deemed obtained unless the TA recipient objects to such dissemination within 60 days of the transmittal of the TA report. ${ }^{13} 14$ The transmittal letter or other transmittal document must expressly refer to this 60 -day period. ${ }^{15}$

(b) Dissemination of other types of final TA advice to Executive Directors and members of their staff.

$>$ Other types of final TA advice may be shared with the Executive Director for the country of the TA recipient, unless the latter specifically requests otherwise.

$>$ With respect to other Executive Directors and members of their staff, access to other types of final TA advice may be obtained, upon request, provided the TA recipient does not specifically object to such sharing within 60 days. Specifically, the

\footnotetext{
${ }^{13}$ As mentioned above, staff should note that except for cases where ex ante irrevocable consent may be required for externally financed TA, TA recipients may withdraw their consent to disseminate any time prior to actual dissemination of a TA report.

14 The objection must be received by the Fund within 60 days from the transmittal letter. After the expiration of the 60-day period, the TA recipient may still object to the dissemination provided the TA report has not yet been disseminated.

${ }^{15}$ See Appendix A for a model transmittal letter containing the standard language to be used for obtaining consent from the TA recipient to disseminate TA reports on a non-objection basis.
} 
objection must be received within 60 days from the date on which Fund staff requests consent from the TA recipient for the dissemination of the final TA advice.

\section{B. Dissemination of Final TA Advice, Including TA Reports, Outside the Fund}

\section{Dissemination of final TA advice beyond the TA recipient, but within the member country, non-member or international agency that has requested Fund TA, as the case may be, is subject to the following rules:}

- The duty of confidentiality is owed to the TA recipient, which is understood to be the direct recipient of the technical services provided by Fund staff. Direct TA recipient means the specific agency or instrumentality within the member country, non-member or international agency, as the case may be, to whom the TA is directed. Accordingly, final TA advice should be disseminated to the direct TA recipient and should be addressed to the head of that agency or instrumentality.

- The Fund encourages the direct TA recipient to share this information with other agencies or instrumentalities of the member country, non-member, or international agency, as the case may be. In addition, Fund staff may share final TA advice with other agencies or instrumentalities of the member country, non-member, or international agency, as the case may be, with the consent of the direct TA recipient. For these purposes, the consent of the direct TA recipient shall be obtained on a non-objection basis. Consent will be deemed given if the direct TA recipient does not object within 60 days. ${ }^{16}$

\section{Dissemination of final TA advice, including TA reports, to donors and TA providers other than the World Bank is governed as outlined below:}

- With the consent of the TA recipient, final TA advice may be shared with donors and other TA providers with legitimate interest, upon their request. For these purposes, the consent of the TA recipient shall be obtained on a no-objection basis. Consent will be deemed given if a TA recipient does not object within 60 days from the TA report's transmittal letter.

- The authoring TA department in consultation with the relevant area department must determine that the donor or TA provider has a legitimate interest in the final TA advice in question. For purposes of developing specific guidelines on this matter to its own staff, the head of a TA department should take into account that parties with a "legitimate interest" in

\footnotetext{
${ }^{16}$ For final TA reports, the consent of the TA recipient, on a non-objection basis, will be obtained by Fund staff through the transmittal letter. See Appendix A for a model letter with standard language. An objection must be received by the Fund within 60 days from the transmittal letter. Alternatively, the TA recipient can give explicit consent to disseminate before the end of the 60-day period, when there is a need to speed up the process of sharing the final TA report. As regards the dissemination of other types of final TA advice, the objection must be received within 60 days from the date on which Fund staff request consent from the TA recipient. After the expiration of the 60 -day period, the TA recipient may still object to the dissemination provided the TA report has not been yet disseminated.
} 
receiving a copy of the written version of the final TA advice include: (a) a donor who is financing, fully or partially, a TA project out of which the requested report has been produced; and (b) a donor or TA provider engaging in related activities in the recipient country in the subject matter of the Fund's TA advice.

- The dissemination of final TA advice to donors and other TA providers with legitimate interest may only take place on the understanding with these recipients that such information shall be kept confidential. ${ }^{17}$

- Some donors require, as a condition for their funding a Fund TA project, that TA reports produced in connection with that project be shared with them. In these cases, Fund management reserves the right to approve such a TA request only if the TA recipient provides its ex ante irrevocable consent to share all TA reports from that project with the applicable donor(s), as a condition for receiving the requested Fund TA. In contrast to the general rule described in paragraph 12 above, in cases involving ex ante irrevocable consent, the TA recipient would not be able to withdraw its consent once TA provision has begun.

\section{Dissemination of final TA advice, including TA reports, to World Bank staff shall be handled in the following manner:}

\section{(a) Dissemination to World Bank staff of final TA advice provided to Fund members:}

$>$ With respect to TA provided to Fund members, under a special procedure stemming from the Concordat on Bank-Fund collaboration, ${ }^{18}$ Fund staff may share final TA advice, including TA reports, with World Bank staff upon request, without the need for obtaining the TA recipient's explicit consent. ${ }^{19}$ In this regard, it is understood that Fund members have been placed on notice that final TA advice, including TA reports, will be shared with Bank staff and, in requesting Fund TA in full knowledge of these rules, are presumed to have implicitly consented to such disclosure.

Dowever, as with other documents shared with Bank staff pursuant to the FundBank Concordat, for example UFR or Article IV consultation documents, Fund staff retain discretion as to whether any particular TA report should be shared with Bank

\footnotetext{
17 See Appendix C for a model communication containing the standard language to be used.

18 The IMF-World Bank Concordat; IMF; March 31, 1989.

19 If confidential information is disclosed to Bank staff, such information is shared on the understanding that the Bank will take practical steps to safeguard its confidentiality, in particular, by treating it within the Bank in the same way that the Fund treats that information within the Fund. In particular, information classified as "CONFIDENTIAL" is disclosed to the Bank on the understanding that it will be made available within the Bank only to those with a "need to know". Information classified as "STRICTLY CONFIDENTIAL" is disclosed to the Bank on the understanding that it will be made available within the Bank only to those with a "strict need to know". In any event, Bank staff shall not disclose classified information shared with it beyond the Bank.
} 
staff. In this regard, it is always open for authoring TA departments to consult the TA recipient prior to sharing TA reports with Bank staff. To the extent a TA recipient objects to the sharing with Bank staff of a particular TA report, Fund staff should respect those wishes.

$>$ Staff should also keep in mind the Joint Management Action Plan (JMAP) for Enhancing Bank-Fund Collaboration, which encourages information sharing and collaboration and contains general guidance on the sharing with Bank staff of documents, including those related to TA. ${ }^{20}$

\section{(b) Dissemination to World Bank staff of final TA advice provided to non- members and international agencies:}

$>$ With respect to Fund TA provided to non-members or international agencies, there is no existing understanding that TA reports may be shared with World Bank staff. Accordingly, staff would need to obtain the explicit consent of the TA recipient before any disclosure to the Bank staff.

\section{The rules for dissemination of final TA advice, including TA reports, to the general public (i.e., publication) are set forth below.}

- All types of final TA advice may be published, and the Fund specifically encourages the publication of TA reports. Accordingly, staff should proactively encourage TA recipients to agree to publication of TA reports by the Fund. Staff should also encourage TA recipients to publish Fund TA reports on their own websites.

- Publication by the Fund of any final TA advice requires the explicit consent ${ }^{21}$ of the TA recipient and the approval of head of the authoring TA department, in consultation with the relevant area department. ${ }^{22}$ As noted earlier, the TA recipient may withdraw its consent to publication at any time prior to publication.

- Publication by the TA recipient of any final TA advice on its own website or in another form requires the approval of the head of the authoring TA department in consultation with the relevant area department. ${ }^{23}$

\footnotetext{
20 See Enhancing Collaboration-Joint Management Action Plan; September 24, 2007.

21 The process for obtaining consent for publication differs from that for other forms of dissemination, i.e., for publication, a communication is required from the recipient that it agrees to publication.

22 It is Fund practice that when TA reports (which are a form of final TA advice) are published, such documents are circulated to the Executive Board for information prior to their publication. As of September 19, 2012, approval for such circulation has been delegated by management to heads of departments authoring TA reports, in consultation with the relevant area department. Such delegation does not preclude authoring departments from flagging any relevant issues to management in advance of Board circulation.

23 The procedure described in footnote 22 would also apply.
} 
- In line with current practice, when a TA report or any other type of final TA advice is to be published, prior to its publication by the Fund or the TA recipient, the TA report or other type of final TA advice should be circulated to the Executive Board for its information in the form in which it is to be published (i.e., after any deletions or corrections, as discussed below, have been made).

- Prior to the publication of a TA report or any other type of final TA advice, sensitive information may be removed from the document. In addition, factual corrections and corrections required to ensure that the views of the TA recipient and Fund staff are accurately characterized in the document may also be introduced. In particular, the following rules shall apply:

\section{(a) Deletions}

$>$ Prior to publication, deletions may be proposed to management by the TA recipient, provided the relevant material is not already in the public domain and qualifies as: (i) highly-market sensitive information; or (ii) policy intentions whose premature disclosure would seriously undermine the ability of the TA recipient to implement the proposed policy.

$>$ When deletions are proposed, staff of the authoring TA department will provide staff of other relevant departments, including the area department, the opportunity to review and comment on the proposal.

$>$ Following the interdepartmental review process noted above and in light of the recommendations made by staff, management will make the decisions on the proposed deletions, and may take into consideration other factors in addition to the criteria mentioned above.

$>$ Before a TA report or other type of final TA advice is published, the following shall be removed from the document: (i) references to unpublished Fund documents, (ii) certain internal processes that are not disclosed to the public under existing policies, including inquiries regarding possible misreporting and breaches of members' obligations, and (iii) discussions of a breach of obligation under Article VIII, Section 5 or misreporting that the Managing Director has proposed to be treated as de minimis in nature.

\section{(b) Corrections}

$>$ Corrections may be proposed to resolve: (i) data or typographical errors; (ii) factual mistakes; and (iii) mischaracterization of views expressed by either, the TA recipient, or by Fund staff from departments in the context of the internal review process.

$>$ When corrections are proposed, staff of the authoring TA department will provide staff of other relevant departments, including the area department, with the opportunity to review and comment on the proposal. 
$>$ Following the interdepartmental review process noted above and in light of the recommendations made by staff, management will make the decisions on the proposed corrections.

(c) Management's objection to publication

In order to maintain the intellectual integrity of the Fund's TA advice, and to preserve the substantive thrust of recommendations made in any TA report or other type of final TA advice, management may withhold its consent to the publication of such document if management disagrees with the deletions or corrections proposed by the TA recipient.

\section{IMPLEMENTATION OF THE GUIDELINES}

\section{A. General Issues}

19. Under the relevant General Administrative Order, management has generally delegated decisions on dissemination of information to heads of departments. ${ }^{24}$ In this regard, unless as otherwise specifically indicated in these guidelines, TA-providing departments shall be responsible for implementation of the procedures specified in the guidelines.

20. In implementing these guidelines, departments should keep in mind the broader context from which these procedures flow, i.e., that, as a general legal principle, Fund management and staff may not disclose information that a member or other party has provided to them in confidence, unless that party consents to such disclosure. A determination that particular information has been provided in confidence is based upon an examination of all the surrounding circumstances, including the nature of the information provided; at issue is the question whether there was an understanding between staff and the other party that such information would not be disclosed without that other party's consent. This understanding can be express or implied.

21. Departments should consult ICD and LEG whenever issues concerning the implementation of these guidelines are unclear.

\section{B. Reference to Guidelines Upon Requests for TA}

22. Whenever staff discuss the possibility of TA, it would be desirable that the guidelines be highlighted to the potential TA recipient. In any case, upon receiving a request for TA, staff should ensure that the TA recipient is made aware of the existence and general content of these guidelines. In this regard, in responding affirmatively to a request for Fund TA, staff may wish either to attach a copy of the guidelines or include a link to the Fund's external website in the response, underscoring that in certain cases, final TA advice may be shared within and outside the

${ }^{24}$ The General Administrative Order No. 35, Rev. 2 on Information Security - Policies Regarding Classified Documents 
Fund on a non-objection basis in accordance with the procedures set forth in these guidelines. This is particularly important in cases in which the request for Fund TA comes from a non-member or an international agency that may not be appraised of the content of these guidelines in the same way as member countries are. Further reminders to the TA recipient of the existence and content of the guidelines should be provided at the start and end of TA missions, and in documents transmitting final TA advice.

\section{Categorization of TA Information and Recipients of TA Information}

23. Upon receiving a request to disseminate particular TA information, staff should categorize the requested TA information according to the categories of TA information listed in paragraph $\mathbf{5}$ above. To the extent that particular TA information is difficult to fit within any of the listed categories, resulting in lack of clarity as to how the information should be treated under the guidelines, staff should consult ICD and LEG for further guidance.

\section{On occasion, staff may be faced with requests for TA dissemination from external} parties other than the most common possibilities listed in paragraph $\mathbf{5}$ above. These may include academics and researchers, nongovernmental organizations and private sector entities providing technical assistance, or various entities in civil society. If staff is unsure of how to handle such requests, ICD and LEG should be consulted.

\section{Coming into Force of Guidelines}

25. These guidelines became effective on May 1, 200925. To aid in bringing the guidelines to the notice of potential TA recipients:

- A communication was sent to all Fund members notifying them of these guidelines and attaching thereto a copy of the guidelines. A similar notice was sent to the World Bank and other international organizations and agencies with which Fund documents are shared under the Fund's Transmittal Policy.

- The guidelines are posted on the Fund's external website following their circulation to the Executive Board for its information.

- In discussing possible TA requests, it would be desirable for departments to inform the member, non-member or international agency requesting Fund TA of the dissemination procedures.

\footnotetext{
25 The guidelines were updated in June 2013 to reflect management's decision to delegate to Heads of Departments approval of circulation of final technical assistance advice to the Executive Board. The revision also clarified a few procedural details. The guidelines have now been updated to reflect the authority reserved to Fund management and TA recipients to provide explicit consent for the dissemination of TA information in scenarios not specifically envisaged in these guidelines.
} 


\section{Appendix A: Model Transmittal Letter ${ }^{1}$}

[Date]

Mr./Ms. ---:

[Position]

[Ministry of --/ Central Bank of --/Other]

[Address]

Dear Mr./Ms. ---:

Please find enclosed [\#] copies -also available in electronic version- of the final technical assistance (TA) report entitled [Title of the TA report] prepared by the [date of mission and authoring TA department] led by [name of mission chief]. The report's recommendations are based upon the mission's findings [at the time of its visit to] [place in which the mission took place]. I understand these recommendations were discussed with [you/ members of your staff] during the mission.

Under IMF policy, TA reports are shared with the IMF's Executive Directors and members of their staff and, upon their request, with donors and other TA providers with legitimate interest, unless you expressly object. Specifically, if we have not received your objection within 60 days of this transmittal letter, you will be deemed to have consented to sharing the enclosed TA report with these recipients (see https://www.imf.org/ /media/Websites/IMF/imported-full-textpdf/external/np/pp/eng/2013/061013.ashx for more information).

The IMF also encourages the publication of TA reports. If you agree to publication of the enclosed report on the IMF website, I would be grateful if you could sign and return the authorization set forth below since your explicit consent is required to publish the TA report. You can also decide to publish the report through your own outlets with IMF approval. In both cases, we will undertake the needed procedural steps as soon as we hear back from you.

\footnotetext{
1 The language in this letter should be used as a model for the transmittal of finalized TA reports to the TA recipient. The language in this letter may also be used in the transmittal of other types of final TA advice if the circumstances so require.
} 
I hope the recommendations of the report will be helpful to [ briefly describe the purpose of recommendations].

Sincerely yours,

[Head of Authoring TA department / regional technical assistance center coordinator ${ }^{2}$ ]

We hereby authorize the IMF to publish the report entitled [Title of the TA report] on the IMF external website.

Signature:

Date:

\author{
Enclosures: [\#] \\ cC: \\ Executive Director
}

${ }^{2}$ Note for TA authoring departments:

For TA reports prepared by regional technical assistance centers (RTACs) (resident advisors or short-term experts), after providing adequate time for review and consultation, and following final approval by the appropriate TA department, the transmittal letter should be signed and sent by the RTAC Coordinator. The authority for transmittal cannot be delegated to short-term experts and resident advisors, given that it is the Fund that provides the TA and should remain accountable for TA products. For TA reports prepared from a mission fielded by HQ (financed or not financed by an RTAC, and including or not including RTAC resident advisors or short-term experts: the transmittal letter should be sent by the TA department and signed by the director of the same department, or a staff member from the same department authorized by the director to sign. 


\section{Appendix B: Model Disclaimer}

1. All Fund TA reports should include the following disclaimer:

"The contents of this report constitute technical advice provided by the staff of the International Monetary Fund (IMF) to the authorities of a [ member country][non-member][international agency] (the "TA recipient") in response to their request for technical assistance. This report (in whole or in part) or summaries thereof may be disclosed by the IMF to IMF Executive Directors and members of their staff, as well as to other agencies or instrumentalities of the TA recipient, and upon their request, to World Bank staff, and other technical assistance providers and donors with legitimate interest lif applicable only] members of the Steering Committee of [name of RTAC of TTF], unless the TA recipient specifically objects to such disclosure (see Operational Guidelines for the Dissemination of Technical Assistance Information-[add hyperlink]). Publication or Disclosure of this report (in whole or in part) or summaries thereof to parties outside the IMF other than agencies or instrumentalities of the TA recipient, World Bank staff, other technical assistance providers and donors with legitimate interest lif applicable only] members of the Steering Committee of [name of RTAC of TTF] shall require the explicit consent of the TA recipient and the IMF's [authoring] Department."

2. In disseminating other types of final TA advice staff may use this disclaimer if the circumstances so require. 


\section{Appendix C}

\section{A. Model Institutional Communication on Confidentiality for Donors (including members} of a Steering Committee of regional technical assistance centers or topical trust funds) and TA Providers other than the World Bank Requesting TA Information ${ }^{1}$

"[Date]

[Donor/ Other TA Provider]

[Address]

Dear Mr./Ms. ---:

In accordance with the IMF policies and procedures on dissemination of TA information (seehyperlink to Operational Guidelines), for purposes of releasing such information, recipients need to explicitly agree to treat that information as confidential. Accordingly, we hereby request [your organization / the Ministry of Finance of [member], as part of the Steering Committee of [name of RTAC] / the Central Bank of [member], as part of the Steering Committee of [name of RTAC]] to confirm that it agrees that any information contained, or referred to in any TA information it may receive from the IMF, shall be treated by [your organization / the Ministry of Finance of [member] / the Central Bank of [member]] as confidential and will be solely for the internal use of [your organization / the Ministry of Finance of [member] / the Central Bank of [member]].

Unless the express authorization of the IMF and the TA recipient is granted, the information referred to above shall not be disclosed either orally or in writing outside [your organization / the Ministry of Finance of [member] / the Central Bank of [member]]. These understandings will become effective on the date on which this letter is returned to the IMF duly signed and dated by an authorized representative of [your organization / the Ministry of Finance of [member] / the Central Bank of [member]].

Sincerely yours,

[Director Institute for Capacity Development /Center Coordinator [name of RTAC]]

[name of Organization/Ministry of Finance/Central Bank] [signature / date]"

\footnotetext{
${ }^{1}$ This communication will be sent to donors and TA provider other than the World Bank to obtain their prior and explicit confirmation of the confidentiality understandings.
} 


\section{B. Confirmation of Understandings on Confidentiality ${ }^{2}$}

"In accordance with the IMF policies and procedures on dissemination of TA information (seehyperlink to Operational Guidelines), and for purposes of releasing the requested document, [your organization / the Ministry of Finance of [member] / the Central Bank of [member]] has agreed that any information contained, or referred to in the requested document, shall be treated as confidential and will be solely for the internal use of [your organization / the Ministry of Finance of [member] / the Central Bank of [member]]. Unless the express authorization of the IMF and the TA recipient is granted, the information referred to above shall not be disclosed either orally or in writing outside your organization."

\footnotetext{
2 This language will be inserted in the letter transmitting the requested TA information to a donor or TA provider that
} has already confirmed the confidentiality understandings. 


\section{Appendix D}

\begin{tabular}{|c|c|c|c|c|c|c|}
\hline \multirow{3}{*}{$\begin{array}{l}\text { CATEGORY OF TA } \\
\text { INFORMATION }\end{array}$} & \multicolumn{6}{|c|}{ DISSEMINATION OF TA INFORMATION TO RECIPIENTS } \\
\hline & \multicolumn{2}{|c|}{ Inside the Fund } & \multicolumn{4}{|c|}{ Outside the Fund } \\
\hline & $\begin{array}{l}\text { Fund } \\
\text { Staff }\end{array}$ & $\begin{array}{l}\text { Executive } \\
\text { Directors }\end{array}$ & $\begin{array}{l}\text { Direct TA } \\
\text { Recipient }\end{array}$ & World Bank & $\begin{array}{c}\text { Donors and Other TA } \\
\text { Providers }^{1}\end{array}$ & $\begin{array}{c}\text { General } \\
\text { Public } \\
\text { (Publication) }\end{array}$ \\
\hline $\begin{array}{l}\text { The Fact of and } \\
\text { Subject-Matter of TA } \\
\text { (Not considered } \\
\text { confidential, unless } \\
\text { TA recipient requests } \\
\text { otherwise) }\end{array}$ & $\begin{array}{c}\text { Available } \\
\text { under Fund's } \\
\text { General } \\
\text { Administrative } \\
\text { Order No. 35, } \\
\text { Rev. } 2\end{array}$ & $\begin{array}{l}\text { Available in staff } \\
\text { reports }\end{array}$ & Available & Ordinarily available $e^{5}$ & Ordinarily available $\mathrm{e}^{23}$ & $\begin{array}{l}\text { May be made } \\
\text { publicly available }\end{array}$ \\
\hline $\begin{array}{c}\text { Information Related } \\
\text { to the Administration } \\
\text { of TA } \\
\text { (Not considered } \\
\text { confidential, unless } \\
\text { TA recipient requests } \\
\text { otherwise) }\end{array}$ & $\begin{array}{c}\text { Available } \\
\text { under Fund's } \\
\text { General } \\
\text { Administrative } \\
\text { Order No. 35, } \\
\text { Rev. } 2\end{array}$ & $\begin{array}{l}\text { Available }^{2} \text { (results of } \\
\text { TA evaluations } \\
\text { available annually } \\
\text { under the Fund's TA } \\
\text { Evaluation Program) }\end{array}$ & Available & Ordinarily available ${ }^{23}$ & Ordinarily available ${ }^{23}$ & $\begin{array}{l}\text { May be made publicly } \\
\text { available }\end{array}$ \\
\hline
\end{tabular}

${ }^{1}$ The term "donor" includes members of a Steering Committee, such as for regional technical assistance centers or topical trust funds funded through multi-donor accounts. The term "other TA provider" means any official bilateral or multilateral agency or instrumentality of the public sector that provides TA.

2 Unless the TA recipient specifically indicates otherwise or withdraws its consent any time prior to dissemination (except for the cases when ex-ante irrevocable consent was granted).

3 Upon request made orally, in writing, or by electronic means, i.e. a click on a secured website

4 Including but not limited to details regarding the project framework, monitoring and evaluation, budget figures, funding source, terms of reference and timing of missions. In this category, Fund staff would not disclose information about third parties that they would normally regard as confidential (e.g., information on the terms of employment of TA expert) 


\begin{tabular}{|c|c|c|c|c|c|c|}
\hline $\begin{array}{l}\text { Information Forming } \\
\text { the Basis of TA Advice } \\
\text { (Considered } \\
\text { confidential and } \\
\text { generally not made } \\
\text { available beyond } \\
\text { Fund staff) }\end{array}$ & $\begin{array}{c}\text { Available } \\
\text { under Fund's } \\
\text { General } \\
\text { Administrative } \\
\text { Order No. } 35 \text {, } \\
\text { Rev. } 2\end{array}$ & Not made available & $\begin{array}{l}\text { Available except for } \\
\text { confidential } \\
\text { information internally } \\
\text { generated by Fund } \\
\text { staff or provided by } \\
\text { third parties. In the } \\
\text { latter case, available if } \\
\text { third party consents. }\end{array}$ & $\begin{array}{l}\text { For coordination purposes } \\
\text { and to exploit synergies, } \\
\text { may be made available }{ }^{3} \\
\text { with (i) the prior consent of } \\
\text { the TA recipient (and the } \\
\text { prior consent of a third } \\
\text { party if the latter provided } \\
\text { information on a } \\
\text { confidential basis) and (ii) } \\
\text { the approval of TA } \\
\text { authoring department }\end{array}$ & $\begin{array}{l}\text { For coordination purposes and } \\
\text { to exploit synergies, may be } \\
\text { made available }{ }^{3} \text { with (i) the prior } \\
\text { consent of the TA recipient (and } \\
\text { the prior consent of a third party } \\
\text { if the latter provided information } \\
\text { on a confidential basis) and (ii) } \\
\text { the approval of TA authoring } \\
\text { department }^{25}\end{array}$ & $\begin{array}{l}\text { Generally not made } \\
\text { publicly available }\end{array}$ \\
\hline $\begin{array}{l}\text { Final TA Advice } \\
\text { (Considered } \\
\text { confidential and may } \\
\text { be made available } \\
\text { only with the consent } \\
\text { of the TA recipient) }\end{array}$ & $\begin{array}{c}\text { Available under } \\
\text { Fund's General } \\
\text { Administrative } \\
\text { Order No.35, } \\
\text { Rev. } 2\end{array}$ & $\begin{array}{l}\text { (a) Executive Director } \\
\text { for the country of the } \\
\text { TA recipient: } \\
\text { Available }^{2} \\
\text { (b) Other Executive } \\
\text { Directors and } \\
\text { members of their } \\
\text { staff: } \\
\text { Available with the } \\
\text { consent of the TA } \\
\text { recipient obtained } \\
\text { on a } 60 \text {-day } \\
\text { nonobjection basis }{ }^{2}\end{array}$ & $\begin{array}{l}\text { Available. } \\
\text { (staff should } \\
\text { encourage the TA } \\
\text { recipient to share this } \\
\text { information with other } \\
\text { agencies or } \\
\text { instrumentalities within } \\
\text { the TA recipient) With } \\
\text { direct TA recipient's } \\
\text { consent Fund staff may } \\
\text { share final TA advice } \\
\text { with other agencies or } \\
\text { instrumentalities of the } \\
\text { member country, non- } \\
\text { member, or } \\
\text { international agency, } \\
\text { as the case may be, on } \\
\text { a non-objection basis. }\end{array}$ & $\begin{array}{l}\text { (a) Final TA advice provided } \\
\text { to Members: } \\
\text { Available }{ }^{23} \text { under the } \\
\text { Fund-Bank Concordat } \\
\text { (unless TA recipient objects } \\
\text { after being consulted by the } \\
\text { authoring TA department) } \\
\text { (b)Final TA advice provided } \\
\text { to Non-members and } \\
\underline{\text { international agencies: }} \\
\text { Available }{ }^{3} \text { with the explicit } \\
\text { consent of the TA recipient. }\end{array}$ & $\begin{array}{l}\text { Available } \text {. }^{23} \text { with the consent of the } \\
\text { TA recipient obtained on a } \\
60 \text {-day non-objection basis }{ }^{6} \text { if } \\
\text { "legitimate interest"7 and the } \\
\text { understanding that the } \\
\text { information should be kept } \\
\text { confidential }^{8} \\
\text { Ex ante irrevocable consent. In } \\
\text { some cases of externally financed } \\
\text { TA, management reserves the } \\
\text { right to approve a request for TA } \\
\text { to be financed by donor(s) only if } \\
\text { the TA recipient provides its ex } \\
\text { ante irrevocable consent to share } \\
\text { all TA reports from that project } \\
\text { with the relevant donor(s). }\end{array}$ & $\begin{array}{l}\text { Staff should } \\
\text { proactively encourage } \\
\text { TA } \\
\text { recipient to explicitly } \\
\text { consent }^{2} \text { to publication } \\
\text { on its own website } \\
\text { and/or on the Fund's } \\
\text { external websites, } \\
\text { pending approval by } \\
\text { the authoring TA } \\
\text { department. } \\
\text { Publication subject to } \\
\text { special policy on } \\
\text { deletions and } \\
\text { corrections prior to } \\
\text { publication. }\end{array}$ \\
\hline
\end{tabular}

\footnotetext{
${ }^{5}$ In consultation with the relevant area department

${ }^{6}$ Which should not prevent the TA recipient from giving its explicit consent to disseminate before the end of the 60 -day period, when there is a need to speed the process of sharing the TA report.

${ }^{7}$ As determined by the authoring TA department in consultation with the relevant are a department. This includes donors financing the project or engaging in related activities with the recipient.

${ }^{8}$ See Appendix $C$ for a model communication containing the standard language to be used. Alternatively, such language could be inserted on a case-by-case basis into a contribution agreement signed with a donor.
} 


\title{
INTERNATIONAL MONETARY FUND
}

June 10, 2013 DISSEMINATION OF TECHNICAL ASSISTANCE

March 198, 2020

\section{STAFF OPERATIONAL GUIDELINES ON THE}

\author{
INFORMATION
}

\section{EXECUTIVE SUMMARY}

The Staff Operational Guidelines on Dissemination of Technical Assistance Information have been updated to reflect the authority reserved to Fund management and TA recipients to provide explicit consent for the dissemination of TA information in scenarios not specifically envisaged in these guidelines. The Staff Operational Guidelines on Dissemination of Technical Assistance Information have been updated to reflect management's decision to delegate to Heads of Departments approval of circulation of final technical assistance advice to the Executive Board. The revisions also clarify a few procedural details. 
Approved By Sean Hagan and

Sharmini Coorey and

Rhoda Weeks-Brown
Prepared by Staff from the Legal Department and Institute for Capacity Development, in consultation with other departments

\section{CONTENTS}

I. INTRODUCTION $\underline{3}$

II. SCOPE OF THE OPERATIONAL GUIDELINES____________ $\underline{4}$

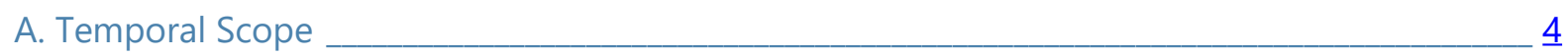

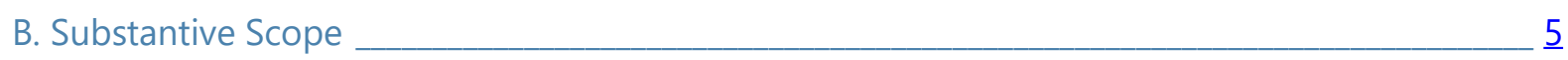

III. PROCEDURES GOVERNING DISSEMINATION OF TA INFORMATION_______ $\mathbf{z}$

A. Information Related to the Fact of TA Provision and Subject-Matter of TA____ $\underline{7}$

B. Information Related to the Administration of TA Projects_______

C. Information Forming the Basis of TA Advice______ $\underline{8}$

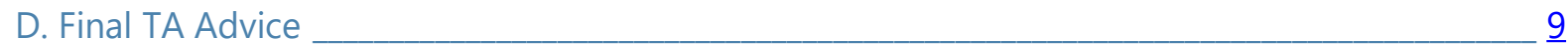

IV. SPECIFIC PROCEDURES FOR DISSEMINATION OF FINAL TA ADVICE _______ 1

A. Dissemination of Final TA Advice within the Fund _________ 10

B. Dissemination of Final TA Advice, Including TA Reports, Outside the Fund _____ 12

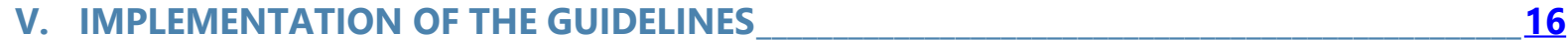

A. General Issues _______ 16

B. Reference to Guidelines Upon Requests for TA _________

C. Categorization of TA Information and Recipients of TA Information ______ 17

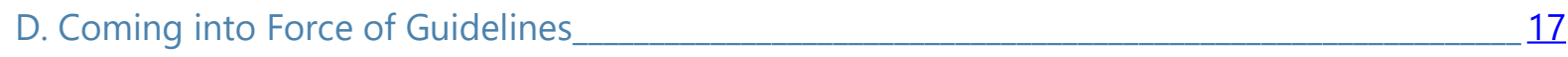

\section{APPENDICES}

Appendix A: Model Transmittal Letter _______ 19

Appendix B: Model Disclaimer________________________________________

Appendix C______ $\underline{22}$

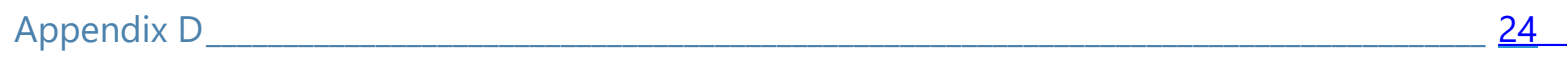




\section{INTRODUCTION}

TA information should be disseminated more widely. The more active sharing of TA information with donors and other TA providers will improve coordination, exploit synergies, and enable the Fund to prioritize and leverage its limited TA resources, thereby fulfilling key objectives under the Paris Declaration on Aid Effectiveness. Moreover, especially from the perspective of their own accountability to their governments and legislators, donors to the Fund's TA program have a legitimate interest in receiving information on TA that is financed by them. For TA recipient countries, the wider dissemination of TA information among different government agencies will strengthen ownership and facilitate the more effective implementation of TA recommendations. More generally, through publication, the membership and the public at large will benefit from a better understanding of best practices, and the Fund's experiences in the provision of TA.

\section{New Guidelines on Dissemination of TA Information: Where to Find What?}

The notes lay out:

$\rightarrow$ Which TA information falls under the new procedures (15), which information is not covered by these procedures ( $(16-7)$ and which different types of information should be distinguished (โ5).

$\rightarrow$ How to treat different types of information (โ8-1211):

- Related to the fact of TA provision and subject matter of TA.

- Related to the administration of TA projects

- Forming the basis of TA advice

- Final TA advice.

$\rightarrow$ How to disseminate final TA advice to:

- Fund staff ( $(\pi 132)$

- Executive Director's's offices ( $(11433)$

- Outside the Fund ( $(14 \underline{5})$, including for the World Bank (\$1 $\underline{76})$, donors and TA providers other than the World Bank ( $(15 \underline{6})$, and the general public ( $(17 \underline{8})$

$\rightarrow$ How to implement the new procedures, including the role of departments (1198-201), the role of staff ( $(22 \underline{21}-2 \underline{4} 3)$ and communication of the guidelines to the public (12 $\underline{5} 4)$. 
1. In "Dissemination of Technical Assistance Information" (SM/08/97, Supp. 1, 4/3/08), management set out a framework for streamlined and strengthened procedures for the wider dissemination of technical assistance-related information ("TA Information", as defined in these guidelines) and stated its intention to issue guidelines to the staff setting forth the new procedures. ${ }^{1}$ Directors took note of management's intention to establish the new procedures and agreed with the objectives underpinning the call for wider dissemination, i.e., to facilitate more systematic and effective dissemination of TA Information including through encouraging publication, while safeguarding confidential information and the candidness of Fund advice. Directors further supported the planned publication of the guidelines containing the new procedures. $^{2}$

2. As was noted in SM/08/97, Supp.1, in several circumstances, the consent of the TA recipient for dissemination of certain types of TA Information will be deemed granted unless the TA recipient explicitly objects to such dissemination. In this regard, as further elaborated below, these guidelines place potential TA recipients on notice that, in requesting Fund TA they will be deemed to have consented to the dissemination of certain types of TA information, unless they explicitly object. To provide such notice, the Fund will take a number of measures described below, including publication of the guidelines and their notification to members and other potential TA recipients. It should be noted, however, that except for those cases in which an ex-ante irrevocable consent may be required for externally-financed TA (see paragraph 156, last bullet below), once the consent to disseminate has been granted, implicitly or explicitly, such consent may be withdrawn by the TA recipient or a third party that provided confidential information to Fund staff any time prior to actual dissemination of the information in question.

3. In accordance with the foregoing, operational guidelines for the staff are set forth below. For ease of reference, a summary of the new procedures is presented in the Attachment.

\section{SCOPE OF THE OPERATIONAL GUIDELINES}

\section{A. Temporal Scope}

4. The new procedures set forth in these guidelines will apply only to TA information concerning TA projects approved on or after the effective date of May 1, 2009 established in paragraph $2 \underline{5} 4$ below.

\footnotetext{
${ }^{1}$ Dissemination of Technical Assistance Information; IMF; April 3, 2008.

2 Enhancing the Impact of IMF Technical Assistance; IMF; May 20, 2008.
} 


\section{B. Substantive Scope}

\section{The guidelines apply to the dissemination within and outside the Fund of all TA Information (excluding the ones covered under paragraphs 6 and 7). In particular:}

\section{- The following non-exhaustive categories of TA information are subject to the guidelines:}

(a) The fact of the provision of TA and the subject matter of TA;

(b) Information on the administration of TA projects (such as details regarding the project framework, monitoring and evaluation, budget figures, funding source, and timing of missions);

(c) Information, received or generated by Fund staff, that forms the basis of Fund TA advice. For purposes of the guidelines the term "information forming the basis of TA advice" includes not only information received by Fund staff from the TA recipient or third parties that is used as a basis for staff's analysis, but also all information produced or generated by Fund staff in the process of providing TA to a TA recipient, including drafts of the TA advice prepared by Fund staff before final TA advice is provided (see paragraph 5(d) below);

(d) Final TA advice. For purposes of the guidelines "final TA advice" means the output of the TA provided by Fund staff at the request of a TA recipient once it is in the final form under which it will be delivered by the Fund staff to the TA recipient. This category consists of final TA advice conveyed by Fund staff to the recipient of TA in the form of TA reports, other final documents such as finalized draft legislation or final aide-mémoires, e-mails, or orally.

- The guidelines will apply to the dissemination of TA information to the following nonexhaustive list of recipients:

(a) the TA recipient and other agencies or instrumentalities within the member country, non-member or international agency to which Fund TA is provided. For purposes of the guidelines, the term "TA recipient" means the governmental or intergovernmental agency or instrumentality that is the direct recipient of Fund TA within member countries, nonmembers and international agencies. Non-members and international agencies are included in this definition since, under Rule N-16(d) of the Fund's Rules and Regulations, the Fund may provide TA to them upon the prior approval of the Executive Board;

(b) Executive Directors and members of their staff;

(c) donors and other TA providers. For purposes of the guidelines the term "donor" includes any official bilateral or multilateral agency or instrumentality of the public 
sector that provides grants or concessional financing for TA. The term donor also includes parties other than the TA recipient and donors to a specific TA project who are members of Steering Committees, such as for regional technical assistance centers or topical trust funds funded through multi-donor subaccounts. Also, the term "other TA provider" means any official bilateral or multilateral agency or instrumentality of the public sector that provides TA;

(d) Fund staff; and

(e) the general public.

\section{The guidelines do not apply to the following types of TA-related information:}

(a) FSAP Reports. The guidelines do not apply to the dissemination of information derived from the Financial Sector Assessment Program (FSAP), a form of technical assistance, since the handling of such information is subject to a separate regime reflecting understandings reached between the managements of the Fund and the World Bank. ${ }^{3}$ More information on this regime for FSAP reports is available in the Guidance Note on the Fund's Transparency Policy. ${ }^{4}$

(b) ROSCs. The guidelines do not apply to the dissemination of these reports since the Executive Board has decided that, as documents circulated to the Board, the dissemination of these reports shall be governed by the Transparency Policy Decision. ${ }^{5}$

(c) Safeguards Assessment Reports. In certain contexts, safeguards assessments conducted by the staff constitute the provision of technical assistance. However, these guidelines do not apply to the dissemination of safeguards reports, which are subject to a separate disclosure regime under the safeguards assessment policy.

\section{The guidelines do not apply to dissemination of TA information that is governed by} the Board-established transmittal and open archives policies.

- Transmittal Policy. The transmittal policy governs the routine transmittal (i.e., on a regular basis) of certain types of reports (including TA reports) to certain international agencies that

\footnotetext{
${ }^{3}$ See Confidentiality Protocol-Protection of Sensitive Information in the Financial Sector Assessment Program

${ }^{4}$ See Guidance Note on the IMF's Transparency Policy; IMF; March 12, 2010, as amended, pages 9 (Box 2. Publication of FSAP-related Documents) and 34 (Appendix V).

${ }^{5}$ Review of the IMF's Transparency Policy; IMF; October 5, 2005, as amended.
} 
meet specified criteria (i.e., commonality of operational interests, reciprocal transmittal of comparable documents to the Fund, and confidentiality safeguards). ${ }^{6}$

- Open Archives Policy. TA reports over 20 years old are available to outside persons upon request, provided that reports originally classified "Strictly Confidential" may not be released if the Managing Director finds that the material remains highly confidential or sensitive. ${ }^{7}$

\section{PROCEDURES GOVERNING DISSEMINATION OF TA INFORMATION}

8. The principle underlying the dissemination of TA information is that dissemination requires the consent of both Fund management and the TA recipient. With respect to consent from Fund management, this authority has generally been delegated to the head of the authoring TA department. With respect to consent from the TA recipient, in some instances, this consent may be obtained on a non-objection basis or may be assumed given the subject of the information. This section lays out specific rules for each type of TA information. Further, in line with the above principle, in scenarios not specifically envisaged in these guidelines, such as dissemination short of publication to private-sector parties, dissemination may be authorized to specific parties with the explicit consent of the TA recipient and the approval of Fund management. ${ }^{8}$ The dissemination of confidential information may only take place with the explicit commitment of the recipients that such information shall be kept confidential. ${ }^{9}$ Where information has been received from a third party, the explicit consent of such party will also be required prior to the dissemination of the relevant information.

\section{A. Information Related to the Fact of TA Provision and Subject-Matter of TA}

8. 9. The fact of provision of Fund TA in response to a particular TA request and the general subject matter of that TA is not considered confidential information, unless the TA recipient specifically indicates otherwise at the time of the request for TA.

\footnotetext{
${ }^{6}$ The Transmittal Policy (see Exchange of Documents with other International Agencies; IMF; February 11, 1993, as amended) has rarely been used for routine transmission of TA reports because, unlike use of Fund resources (UFR) and Article IV consultation reports, TA reports are not produced on a regular basis. In addition, some TA providers and donors may not qualify as "international agencies" within the meaning of the policy, and the criterion on commonality of operational interest may be difficult to meet.

${ }^{7}$ See Review of the Fund's' Transparency Policy-Archives Policy; IMF; December 17, 2009, as amended.

${ }^{8}$ In determining whether to provide consent to dissemination of TA information in a scenario not explicitly envisaged in these guidelines, management should take into account, inter alia, the impact of disclosure on the TA project, whether disclosure presents any reputational risks for the Fund, and whether disclosure furthers the underlying objectives of the TA being provided.

9 Please consult with LEG and ICD for the language to be used for this commitment.
} 
- Information in this category would thus ordinarily be made available to Executive Directors in staff reports. In addition, and upon request, ${ }^{10}$ this type of information may be made available to TA providers and donors. The information may also be made available to the general public.

- In those cases, expected to be rare, where the TA recipient explicitly advises Fund staff that it does not want such information to be made available, particularly to the general public, the TA recipient's wishes shall be respected.

\section{B. Information Related to the Administration of TA Projects}

9. 10. Information dealing with the administration of a TA project is not considered confidential, unless the TA recipient specifically indicates otherwise at the time of the request for TA.

- Since this type of information is not considered confidential unless so specified, it may be shared with Executive Directors and members of their staff upon their request. In any event, the results of TA evaluations will continue to be reported to Executive Directors on an annual basis under the Fund's TA Evaluation Program.

- In particular, given the high demand for this information and its importance for coordination among donors, this information would be made readily available to other TA providers and donors upon their request. This information may also be made available to the general public.

- However, Fund staff would not disclose information about third parties (i.e., parties other than the TA recipient and the Fund), including donors who are funding TA projects, that such third parties would normally regard as confidential (e.g., information on the terms of employment of a TA expert).

\section{Information Forming the Basis of TA Advice}

10. 11. Information provided to Fund staff by a TA recipient or a third party, or that is generated by Fund staff in the context of the provision of TA, constitutes information that forms the basis of TA advice.

- Within this category there are two different types of information:

(a) Information provided by the TA recipient or third parties in the context of the provision of Fund TA; and

(b) Information generated by Fund staff in the course of provision of TA before the TA advice is finalized.

\footnotetext{
${ }^{10} \mathrm{~A}$ request, as defined in this document, can be made orally, in writing, or by electronic means, i.e., a click on a secured website of the Fund.
} 
- Information forming the basis of TA advice is presumed confidential and shall only be made available beyond Fund staff, management and the TA recipient in certain circumstances where such sharing is considered necessary to facilitate coordination with donors and other TA providers and to exploit synergies.

- Specifically, the head of the authoring TA department in consultation with the relevant area department may consent to the dissemination of the information referred to in (a) and (b) above, upon request of World Bank staff, donors or other TA providers with legitimate interest, when the TA recipient has also explicitly consented to such dissemination. Where information has been received from a third party, the explicit consent of such party will also be required prior to the dissemination of the relevant information.

- In determining whether to consent to the dissemination of information referred to in (a) and (b) above, the head of the authoring TA department in consultation with the relevant area department will take into account the following considerations:

$>$ The likelihood that the sharing of such information outside of staff, management and the TA recipient could undermine the Fund's ability to obtain all necessary data and information from country authorities and third parties.

$>$ The impact that the disclosure of such information might have on the candor of discussions during a TA project's execution, whether they be in the form of exchanges with country authorities and third parties or internal deliberations among Fund staff.

- This information will generally not be published.

\section{Final TA Advice}

\section{12. Final TA advice is considered confidential information and its dissemination} requires the consent of the TA recipient. Final TA advice may take the form of: (i) TA reports ${ }^{11}$, (ii) other documents containing finalized Fund staff advice including draft legislation or final aidemémoires prepared by Fund staff, and (iii) final advice provided by Fund staff to a TA recipient through emails or orally.

- Staff should note that, except for cases where ex-ante irrevocable consent may be required for externally financed TA in accordance with paragraph $1 \underline{6} 5$ below, TA recipients may withdraw their consent to disseminate any time prior to actual dissemination of final TA advice.

\footnotetext{
${ }^{11}$ In Dissemination of Technical Assistance Information; IMF; April 3, 2008 (paragraph 17) staff used the term "TA reports" to cover all final TA advice, irrespective of whether such advice was technically a TA report. However, operationally, it would be impractical to treat the dissemination of emails and oral TA advice, for example, in the same way that TA reports are treated. For these reasons, the guidelines distinguish between "TA reports" and "other types of final TA advice".
} 
- Since "TA reports" are the main form of delivering final TA advice to TA recipients, Section IV below describes specific procedures for the dissemination of TA reports within and outside the Fund. All TA reports shall include a disclaimer summarizing the Fund's policy for dissemination of this type of information according to the guidelines as set forth in Appendix B.

- Specific rules for the dissemination of final TA advice other than TA reports are also outlined in Section IV below.

\section{SPECIFIC PROCEDURES FOR DISSEMINATION OF FINAL TA ADVICE}

\section{A. Dissemination of Final TA Advice within the Fund}

12. 13. Dissemination of final TA advice to Fund staff is governed by the following procedures:

(a) Specific Rules for Dissemination of TA reports to Fund staff:

> Authoring TA departments are required to ensure that all finalized TA reports, except those classified as "STRICTLY CONFIDENTIAL"12 and FSAP reports, are forwarded to the Institutional Repository.

$>$ Of the TA reports that are forwarded to the Institutional Repository, those that are classified "FOR OFFICIAL USE ONLY" are accessible to all staff, while TA reports classified "CONFIDENTIAL" are accessible to a smaller group of staff, as determined in GAO No. 35, Rev. 2 (i.e., access on a need to know basis). The authoring TA department is responsible for making determinations on what constitutes need to know on a case-by-case basis. In making this determination the authoring TA department should take into account the express or implied understandings reached with the TA recipient, as well as the surrounding circumstances, including the nature of the information contained in the TA report.

\footnotetext{
12 Dissemination of TA reports that are classified as "STRICTLY CONFIDENTIAL" shall follow the rules set forth in General Administrative Order (GAO) No. 35, Rev. 2 ("Information Security-Policies Regarding Classified Documents of November 1, 2007) for dissemination within the Fund, and the Fund's Open Archives Policy for sharing outside the Fund. According to GAO No. 35, Rev. 2, access to a TA report classified as "STRICTLY CONFIDENTIAL" shall be limited to addressees who meet the "strict need to know criterion". Outside the Fund, persons may have access to "STRICTLY CONFIDENTIAL" documents under the Open Archives Policy upon their request, if the documents are over 20 years old, provided, however, that access to those documents will be granted only upon the Managing Director's consent to declassification (see Decision No. 14498-(09/126), as amended. Pursuant to GAO No. 35, Rev. 2, the Managing Director has delegated her authority on declassification under the Open Archives Policy to heads of departments. The Managing Director, with the consent of the TA recipient, may also approve the sharing of TA reports classified as "STRICTLY CONFIDENTIAL" outside the Fund prior to the 20-year period. In these cases, such sharing will take place only if understandings are reached between Fund staff and the outside recipient of the information that such information shall be treated by the latter as strictly confidential.
} 
$>$ TA reports classified as "CONFIDENTIAL" are reclassified automatically "FOR OFFICIAL USE ONLY" after two years, unless the authoring TA department or the relevant area department considers that the sensitivity of the information has not sufficiently diminished.

(b) Dissemination of other types of final TA advice to Fund staff:

Any form of final TA advice may be disseminated to Fund staff in accordance with the classification of the document and the procedures set forth in GAO No. 35, Rev.

\section{14. Dissemination of final TA advice to Executive Directors and members of their} staff is governed by the following procedures:

\section{(a) Dissemination of TA reports to Executive Directors and members of their staff:}

$>$ The general practice of making TA reports available to the Executive Director for the country of the TA recipient, unless the latter specifically requests otherwise, will continue to apply.

$>$ With respect to other Executive Directors and members of their staff, access to TA reports requires the consent of the TA recipient. Consent will be deemed obtained unless the TA recipient objects to such dissemination within 60 days of the transmittal of the TA report. ${ }^{13} 14$ The transmittal letter or other transmittal document must expressly refer to this 60 -day period. ${ }^{15}$

(b) Dissemination of other types of final TA advice to Executive Directors and members of their staff.

$>$ Other types of final TA advice may be shared with the Executive Director for the country of the TA recipient, unless the latter specifically requests otherwise.

$>$ With respect to other Executive Directors and members of their staff, access to other types of final TA advice may be obtained, upon request, provided the TA recipient does not specifically object to such sharing within 60 days. Specifically, the

\footnotetext{
${ }^{13}$ As mentioned above, staff should note that except for cases where ex ante irrevocable consent may be required for externally financed TA, TA recipients may withdraw their consent to disseminate any time prior to actual dissemination of a TA report.

14 The objection must be received by the Fund within 60 days from the transmittal letter. After the expiration of the 60-day period, the TA recipient may still object to the dissemination provided the TA report has not yet been disseminated.

${ }^{15}$ See Appendix A for a model transmittal letter containing the standard language to be used for obtaining consent from the TA recipient to disseminate TA reports on a non-objection basis.
} 
objection must be received within 60 days from the date on which Fund staff requests consent from the TA recipient for the dissemination of the final TA advice.

\section{B. Dissemination of Final TA Advice, Including TA Reports, Outside the Fund}

\section{15. Dissemination of final TA advice beyond the TA recipient, but within the member country, non-member or international agency that has requested Fund TA, as the case may be, is subject to the following rules:}

- The duty of confidentiality is owed to the TA recipient, which is understood to be the direct recipient of the technical services provided by Fund staff. Direct TA recipient means the specific agency or instrumentality within the member country, non-member or international agency, as the case may be, to whom the TA is directed. Accordingly, final TA advice should be disseminated to the direct TA recipient and should be addressed to the head of that agency or instrumentality.

- The Fund encourages the direct TA recipient to share this information with other agencies or instrumentalities of the member country, non-member, or international agency, as the case may be. In addition, Fund staff may share final TA advice with other agencies or instrumentalities of the member country, non-member, or international agency, as the case may be, with the consent of the direct TA recipient. For these purposes, the consent of the direct TA recipient shall be obtained on a non-objection basis. Consent will be deemed given if the direct TA recipient does not object within 60 days. ${ }^{16}$

\section{16. Dissemination of final TA advice, including TA reports, to donors and TA providers other than the World Bank is governed as outlined below:}

- With the consent of the TA recipient, final TA advice may be shared with donors and other TA providers with legitimate interest, upon their request. For these purposes, the consent of the TA recipient shall be obtained on a no-objection basis. Consent will be deemed given if a TA recipient does not object within 60 days from the TA report's transmittal letter.

- The authoring TA department in consultation with the relevant area department must determine that the donor or TA provider has a legitimate interest in the final TA advice in question. For purposes of developing specific guidelines on this matter to its own staff, the head of a TA department should take into account that parties with a "legitimate interest" in

\footnotetext{
${ }^{16}$ For final TA reports, the consent of the TA recipient, on a non-objection basis, will be obtained by Fund staff through the transmittal letter. See Appendix A for a model letter with standard language. An objection must be received by the Fund within 60 days from the transmittal letter. Alternatively, the TA recipient can give explicit consent to disseminate before the end of the 60-day period, when there is a need to speed up the process of sharing the final TA report. As regards the dissemination of other types of final TA advice, the objection must be received within 60 days from the date on which Fund staff request consent from the TA recipient. After the expiration of the 60 -day period, the TA recipient may still object to the dissemination provided the TA report has not been yet disseminated.
} 
receiving a copy of the written version of the final TA advice include: (a) a donor who is financing, fully or partially, a TA project out of which the requested report has been produced; and (b) a donor or TA provider engaging in related activities in the recipient country in the subject matter of the Fund's TA advice.

- The dissemination of final TA advice to donors and other TA providers with legitimate interest may only take place on the understanding with these recipients that such information shall be kept confidential. ${ }^{17}$

- Some donors require, as a condition for their funding a Fund TA project, that TA reports produced in connection with that project be shared with them. In these cases, Fund management reserves the right to approve such a TA request only if the TA recipient provides its ex ante irrevocable consent to share all TA reports from that project with the applicable donor(s), as a condition for receiving the requested Fund TA. In contrast to the general rule described in paragraph $1 \underline{21}$ above, in cases involving ex ante irrevocable consent, the TA recipient would not be able to withdraw its consent once TA provision has begun.

\section{17. Dissemination of final TA advice, including TA reports, to World Bank staff shall be handled in the following manner:}

\section{(a) Dissemination to World Bank staff of final TA advice provided to Fund members:}

$>$ With respect to TA provided to Fund members, under a special procedure stemming from the Concordat on Bank-Fund collaboration, ${ }^{18}$ Fund staff may share final TA advice, including TA reports, with World Bank staff upon request, without the need for obtaining the TA recipient's explicit consent. ${ }^{19}$ In this regard, it is understood that Fund members have been placed on notice that final TA advice, including TA reports, will be shared with Bank staff and, in requesting Fund TA in full knowledge of these rules, are presumed to have implicitly consented to such disclosure.

> However, as with other documents shared with Bank staff pursuant to the FundBank Concordat, for example UFR or Article IV consultation documents, Fund staff retain discretion as to whether any particular TA report should be shared with Bank

\footnotetext{
17 See Appendix C for a model communication containing the standard language to be used.

${ }^{18}$ The IMF-World Bank Concordat; IMF; March 31, 1989.

${ }^{19}$ If confidential information is disclosed to Bank staff, such information is shared on the understanding that the Bank will take practical steps to safeguard its confidentiality, in particular, by treating it within the Bank in the same way that the Fund treats that information within the Fund. In particular, information classified as "CONFIDENTIAL" is disclosed to the Bank on the understanding that it will be made available within the Bank only to those with a "need to know". Information classified as "STRICTLY CONFIDENTIAL" is disclosed to the Bank on the understanding that it will be made available within the Bank only to those with a "strict need to know". In any event, Bank staff shall not disclose classified information shared with it beyond the Bank.
} 
staff. In this regard, it is always open for authoring TA departments to consult the TA recipient prior to sharing TA reports with Bank staff. To the extent a TA recipient objects to the sharing with Bank staff of a particular TA report, Fund staff should respect those wishes.

$>$ Staff should also keep in mind the Joint Management Action Plan (JMAP) for Enhancing Bank-Fund Collaboration, which encourages information sharing and collaboration and contains general guidance on the sharing with Bank staff of documents, including those related to TA. ${ }^{20}$

\section{(b) Dissemination to World Bank staff of final TA advice provided to non- members and international agencies:}

$>$ With respect to Fund TA provided to non-members or international agencies, there is no existing understanding that TA reports may be shared with World Bank staff. Accordingly, staff would need to obtain the explicit consent of the TA recipient before any disclosure to the Bank staff.

\section{18. The rules for dissemination of final TA advice, including TA reports, to the general public (i.e., publication) are set forth below.}

- All types of final TA advice may be published, and the Fund specifically encourages the publication of TA reports. Accordingly, staff should proactively encourage TA recipients to agree to publication of TA reports by the Fund. Staff should also encourage TA recipients to publish Fund TA reports on their own websites.

- Publication by the Fund of any final TA advice requires the explicit consent ${ }^{21}$ of the TA recipient and the approval of head of the authoring TA department, in consultation with the relevant area department. ${ }^{22}$ As noted earlier, the TA recipient may withdraw its consent to publication at any time prior to publication.

- Publication by the TA recipient of any final TA advice on its own website or in another form requires the approval of the head of the authoring TA department in consultation with the relevant area department. ${ }^{23}$

\footnotetext{
20 See Enhancing Collaboration-Joint Management Action Plan; September 24, 2007.

21 The process for obtaining consent for publication differs from that for other forms of dissemination, i.e., for publication, a communication is required from the recipient that it agrees to publication.

${ }^{22}$ It is Fund practice that when TA reports (which are a form of final TA advice) are published, such documents are circulated to the Executive Board for information prior to their publication. As of September 19, 2012, approval for such circulation has been delegated by management to heads of departments authoring TA reports, in consultation with the relevant area department. Such delegation does not preclude authoring departments from flagging any relevant issues to management in advance of Board circulation.

23 The procedure described in footnote $2 \underline{23} 7$ would also apply.
} 
- In line with current practice, when a TA report or any other type of final TA advice is to be published, prior to its publication by the Fund or the TA recipient, the TA report or other type of final TA advice should be circulated to the Executive Board for its information in the form in which it is to be published (i.e., after any deletions or corrections, as discussed below, have been made).

- Prior to the publication of a TA report or any other type of final TA advice, sensitive information may be removed from the document. In addition, factual corrections and corrections required to ensure that the views of the TA recipient and Fund staff are accurately characterized in the document may also be introduced. In particular, the following rules shall apply:

\section{(a) Deletions}

$>$ Prior to publication, deletions may be proposed to management by the TA recipient, provided the relevant material is not already in the public domain and qualifies as: (i) highly-market sensitive information; or (ii) policy intentions whose premature disclosure would seriously undermine the ability of the TA recipient to implement the proposed policy.

D When deletions are proposed, staff of the authoring TA department will provide staff of other relevant departments, including the area department, the opportunity to review and comment on the proposal.

$>$ Following the interdepartmental review process noted above and in light of the recommendations made by staff, management will make the decisions on the proposed deletions, and may take into consideration other factors in addition to the criteria mentioned above.

$>$ Before a TA report or other type of final TA advice is published, the following shall be removed from the document: (i) references to unpublished Fund documents, (ii) certain internal processes that are not disclosed to the public under existing policies, including inquiries regarding possible misreporting and breaches of members' obligations, and (iii) discussions of a breach of obligation under Article VIII, Section 5 or misreporting that the Managing Director has proposed to be treated as de minimis in nature.

\section{(b) Corrections}

$>$ Corrections may be proposed to resolve: (i) data or typographical errors; (ii) factual mistakes; and (iii) mischaracterization of views expressed by either, the TA recipient, or by Fund staff from departments in the context of the internal review process. 
$>$ When corrections are proposed, staff of the authoring TA department will provide staff of other relevant departments, including the area department, with the opportunity to review and comment on the proposal.

$>$ Following the interdepartmental review process noted above and in light of the recommendations made by staff, management will make the decisions on the proposed corrections.

(c) Management's objection to publication

$>$ In order to maintain the intellectual integrity of the Fund's TA advice, and to preserve the substantive thrust of recommendations made in any TA report or other type of final TA advice, management may withhold its consent to the publication of such document if management disagrees with the deletions or corrections proposed by the TA recipient.

\section{IMPLEMENTATION OF THE GUIDELINES}

\section{A. General Issues}

18. 19. Under the relevant General Administrative Order, management has generally delegated decisions on dissemination of information to heads of departments. ${ }^{24}$ In this regard, unless as otherwise specifically indicated in these guidelines, TA-providing departments shall be responsible for implementation of the procedures specified in the guidelines.

19. 20. In implementing these guidelines, departments should keep in mind the broader context from which these procedures flow, i.e., that, as a general legal principle, Fund management and staff may not disclose information that a member or other party has provided to them in confidence, unless that party consents to such disclosure. A determination that particular information has been provided in confidence is based upon an examination of all the surrounding circumstances, including the nature of the information provided; at issue is the question whether there was an understanding between staff and the other party that such information would not be disclosed without that other party's consent. This understanding can be express or implied.

20. 21. Departments should consult ICD and LEG whenever issues concerning the implementation of these guidelines are unclear.

\section{B. Reference to Guidelines Upon Requests for TA}

21. 22. Whenever staff discuss the possibility of TA, it would be desirable that the guidelines be highlighted to the potential TA recipient. In any case, upon receiving a request

${ }^{24}$ The General Administrative Order No. 35, Rev. 2 on Information Security - Policies Regarding Classified Documents 
for TA, staff should ensure that the TA recipient is made aware of the existence and general content of these guidelines. In this regard, in responding affirmatively to a request for Fund TA, staff may wish either to attach a copy of the guidelines or include a link to the Fund's external website in the response, underscoring that in certain cases, final TA advice may be shared within and outside the Fund on a non-objection basis in accordance with the procedures set forth in these guidelines. This is particularly important in cases in which the request for Fund TA comes from a non-member or an international agency that may not be appraised of the content of these guidelines in the same way as member countries are. Further reminders to the TA recipient of the existence and content of the guidelines should be provided at the start and end of TA missions, and in documents transmitting final TA advice.

\section{Categorization of TA Information and Recipients of TA Information}

22. 23. Upon receiving a request to disseminate particular TA information, staff should categorize the requested TA information according to the categories of TA information listed

in paragraph $\mathbf{5}$ above. To the extent that particular TA information is difficult to fit within any of the listed categories, resulting in lack of clarity as to how the information should be treated under the guidelines, staff should consult ICD and LEG for further guidance.

\section{24. On occasion, staff may be faced with requests for TA dissemination from} external parties other than the most common possibilities listed in paragraph $\mathbf{5}$ above. These may include academics and researchers, nongovernmental organizations and private sector entities providing technical assistance, or various entities in civil society. If staff is unsure of how to handle such requests, ICD and LEG should be consulted.

\section{Coming into Force of Guidelines}

24. 25. These guidelines became effective on May 1, 200925. To aid in bringing the guidelines to the notice of potential TA recipients:

- A communication was sent to all Fund members notifying them of these guidelines and attaching thereto a copy of the guidelines. A similar notice was sent to the World Bank and other international organizations and agencies with which Fund documents are shared under the Fund's Transmittal Policy.

- The guidelines are posted on the Fund's external website following their circulation to the Executive Board for its information.

\footnotetext{
25 The guidelines were updated in June 2013 have been updated-to reflect management's decision to delegate to Heads of Departments approval of circulation of final technical assistance advice to the Executive Board. The revisions also clarified $y$ a few procedural details. The guidelines have now been updated to reflect the authority reserved to Fund management and TA recipients to provide explicit consent for the dissemination of TA information in scenarios not specifically envisaged in these guidelines.
} 
- In discussing possible TA requests, it would be desirable for departments to inform the member, non-member or international agency requesting Fund TA of the dissemination procedures. 


\section{Appendix A: Model Transmittal Letter'}

[Date]

Mr./Ms. ---:

[Position]

[Ministry of --/ Central Bank of --/Other]

[Address]

Dear Mr./Ms. ---:

Please find enclosed [\#] copies -also available in electronic version- of the final technical assistance (TA) report entitled [Title of the TA report] prepared by the [date of mission and authoring TA department] led by [name of mission chief]. The report's recommendations are based upon the mission's findings [at the time of its visit to] [place in which the mission took place]. I understand these recommendations were discussed with [you/ members of your staff] during the mission.

Under IMF policy, TA reports are shared with the IMF's Executive Directors and members of their staff and, upon their request, with donors and other TA providers with legitimate interest, unless you expressly object. Specifically, if we have not received your objection within 60 days of this transmittal letter, you will be deemed to have consented to sharing the enclosed TA report with these recipients (see https://www.imf.org/ /media/Websites/IMF/imported-full-textpdf/external/np/pp/eng/2013/ 061013.ashxhttp://w imf.org/external/np/pp/eng/2009/040609.p df for more information).

The IMF also encourages the publication of TA reports. If you agree to publication of the enclosed report on the IMF website, I would be grateful if you could sign and return the authorization set forth below since your explicit consent is required to publish the TA report. You can also decide to publish the report through your own outlets with IMF approval. In both cases, we will undertake the needed procedural steps as soon as we hear back from you.

\footnotetext{
1 The language in this letter should be used as a model for the transmittal of finalized TA reports to the TA recipient. The language in this letter may also be used in the transmittal of other types of final TA advice if the circumstances so require.
} 
I hope the recommendations of the report will be helpful to [ briefly describe the purpose of recommendations].

Sincerely yours,

[Head of Authoring TA department / regional technical assistance center coordinator ${ }^{2}$ ]

We hereby authorize the IMF to publish the report entitled [Title of the TA report] on the IMF external website.

Signature:

Date:

\author{
Enclosures: [\#] \\ CC: \\ Executive Director
}

${ }^{2}$ Note for TA authoring departments:

For TA reports prepared by regional technical assistance centers (RTACs) (resident advisors or short-term experts), after providing adequate time for review and consultation, and following final approval by the appropriate TA department, the transmittal letter should be signed and sent by the RTAC Coordinator. The authority for transmittal cannot be delegated to short-term experts and resident advisors, given that it is the Fund that provides the TA and should remain accountable for TA products. For TA reports prepared from a mission fielded by HQ (financed or not financed by an RTAC, and including or not including RTAC resident advisors or short-term experts: the transmittal letter should be sent by the TA department and signed by the director of the same department, or a staff member from the same department authorized by the director to sign. 


\section{Appendix B: Model Disclaimer}

1. All Fund TA reports should include the following disclaimer:

"The contents of this report constitute technical advice provided by the staff of the International Monetary Fund (IMF) to the authorities of a [ member country][non-member][international agency] (the "TA recipient") in response to their request for technical assistance. This report (in whole or in part) or summaries thereof may be disclosed by the IMF to IMF Executive Directors and members of their staff, as well as to other agencies or instrumentalities of the TA recipient, and upon their request, to World Bank staff, and other technical assistance providers and donors with legitimate interest lif applicable only] members of the Steering Committee of [name of RTAC of TTF], unless the TA recipient specifically objects to such disclosure (see Operational Guidelines for the Dissemination of Technical Assistance Information-[add hyperlink]). Publication or Disclosure of this report (in whole or in part) or summaries thereof to parties outside the IMF other than agencies or instrumentalities of the TA recipient, World Bank staff, other technical assistance providers and donors with legitimate interest lif applicable only] members of the Steering Committee of [name of RTAC of TTF] shall require the explicit consent of the TA recipient and the IMF's [authoring] Department."

2. In disseminating other types of final TA advice staff may use this disclaimer if the circumstances so require. 


\section{Appendix C}

A. Model Institutional Communication on Confidentiality for Donors (including members of a Steering Committee of regional technical assistance centers or topical trust funds) and TA Providers other than the World Bank Requesting TA Information ${ }^{1}$

"[Date]

[Donor/ Other TA Provider]

[Address]

Dear Mr./Ms. ---:

In accordance with the IMF policies and procedures on dissemination of TA information (seehyperlink to Operational Guidelines), for purposes of releasing such information, recipients need to explicitly agree to treat that information as confidential. Accordingly, we hereby request [your organization / the Ministry of Finance of [member], as part of the Steering Committee of [name of RTAC] / the Central Bank of [member], as part of the Steering Committee of [name of RTAC]] to confirm that it agrees that any information contained, or referred to in any TA information it may receive from the IMF, shall be treated by [your organization / the Ministry of Finance of [member] / the Central Bank of [member]] as confidential and will be solely for the internal use of [your organization / the Ministry of Finance of [member] / the Central Bank of [member]].

Unless the express authorization of the IMF and the TA recipient is granted, the information referred to above shall not be disclosed either orally or in writing outside [your organization / the Ministry of Finance of [member] / the Central Bank of [member]]. These understandings will become effective on the date on which this letter is returned to the IMF duly signed and dated by an authorized representative of [your organization / the Ministry of Finance of [member] / the Central Bank of [member]].

Sincerely yours,

[Director Institute for Capacity Development /Center Coordinator [name of RTAC]]

[name of Organization/Ministry of Finance/Central Bank] [signature / date]"

\footnotetext{
${ }^{1}$ This communication will be sent to donors and TA provider other than the World Bank to obtain their prior and explicit confirmation of the confidentiality understandings.
} 


\section{B. Confirmation of Understandings on Confidentiality ${ }^{2}$}

"In accordance with the IMF policies and procedures on dissemination of TA information (seehyperlink to Operational Guidelines), and for purposes of releasing the requested document, [your organization / the Ministry of Finance of [member] / the Central Bank of [member]] has agreed that any information contained, or referred to in the requested document, shall be treated as confidential and will be solely for the internal use of [your organization / the Ministry of Finance of [member] / the Central Bank of [member]]. Unless the express authorization of the IMF and the TA recipient is granted, the information referred to above shall not be disclosed either orally or in writing outside your organization."

\footnotetext{
2 This language will be inserted in the letter transmitting the requested TA information to a donor or TA provider that has already confirmed the confidentiality understandings.
} 


\section{Appendix D}

\begin{tabular}{|c|c|c|c|c|c|c|}
\hline \multirow{3}{*}{$\begin{array}{l}\text { CATEGORY OF TA } \\
\text { INFORMATION }\end{array}$} & \multicolumn{6}{|c|}{ DISSEMINATION OF TA INFORMATION TO RECIPIENTS } \\
\hline & \multicolumn{2}{|c|}{ Inside the Fund } & \multicolumn{4}{|c|}{ Outside the Fund } \\
\hline & $\begin{array}{l}\text { Fund } \\
\text { Staff }\end{array}$ & $\begin{array}{l}\text { Executive } \\
\text { Directors }\end{array}$ & $\begin{array}{l}\text { Direct TA } \\
\text { Recipient }\end{array}$ & World Bank & $\begin{array}{c}\text { Donors and Other TA } \\
\text { Providers }^{1}\end{array}$ & $\begin{array}{c}\text { General } \\
\text { Public } \\
\text { (Publication) }\end{array}$ \\
\hline $\begin{array}{l}\text { The Fact of and } \\
\text { Subject-Matter of TA } \\
\text { (Not considered } \\
\text { confidential, unless } \\
\text { TA recipient requests } \\
\text { otherwise) }\end{array}$ & $\begin{array}{c}\text { Available } \\
\text { under Fund's } \\
\text { General } \\
\text { Administrative } \\
\text { Order No. 35, } \\
\text { Rev. } 2\end{array}$ & $\begin{array}{l}\text { Available in staff } \\
\text { reports }\end{array}$ & Available & Ordinarily available $e^{5}$ & Ordinarily available $\mathrm{e}^{23}$ & $\begin{array}{l}\text { May be made } \\
\text { publicly available }\end{array}$ \\
\hline $\begin{array}{c}\text { Information Related } \\
\text { to the Administration } \\
\text { of TA } \\
\text { (Not considered } \\
\text { confidential, unless } \\
\text { TA recipient requests } \\
\text { otherwise) }\end{array}$ & $\begin{array}{c}\text { Available } \\
\text { under Fund's } \\
\text { General } \\
\text { Administrative } \\
\text { Order No. 35, } \\
\text { Rev. } 2\end{array}$ & $\begin{array}{l}\text { Available }^{2} \text { (results of } \\
\text { TA evaluations } \\
\text { available annually } \\
\text { under the Fund's TA } \\
\text { Evaluation Program) }\end{array}$ & Available & Ordinarily available ${ }^{23}$ & Ordinarily available ${ }^{23}$ & $\begin{array}{l}\text { May be made publicly } \\
\text { available }\end{array}$ \\
\hline
\end{tabular}

${ }^{1}$ The term "donor" includes members of a Steering Committee, such as for regional technical assistance centers or topical trust funds funded through multi-donor accounts. The term "other TA provider" means any official bilateral or multilateral agency or instrumentality of the public sector that provides TA.

2 Unless the TA recipient specifically indicates otherwise or withdraws its consent any time prior to dissemination (except for the cases when ex-ante irrevocable consent was granted).

3 Upon request made orally, in writing, or by electronic means, i.e. a click on a secured website

${ }^{4}$ Including but not limited to details regarding the project framework, monitoring and evaluation, budget figures, funding source, terms of reference and timing of missions. In this category, Fund staff would not disclose information about third parties that they would normally regard as confidential (e.g., information on the terms of employment of TA expert) 


\begin{tabular}{|c|c|c|c|c|c|c|}
\hline $\begin{array}{l}\text { Information Forming } \\
\text { the Basis of TA Advice } \\
\text { (Considered } \\
\text { confidential and } \\
\text { generally not made } \\
\text { available beyond } \\
\text { Fund staff) }\end{array}$ & $\begin{array}{c}\text { Available } \\
\text { under Fund's } \\
\text { General } \\
\text { Administrative } \\
\text { Order No. } 35 \text {, } \\
\text { Rev. } 2\end{array}$ & Not made available & $\begin{array}{l}\text { Available except for } \\
\text { confidential } \\
\text { information internally } \\
\text { generated by Fund } \\
\text { staff or provided by } \\
\text { third parties. In the } \\
\text { latter case, available if } \\
\text { third party consents. }\end{array}$ & $\begin{array}{l}\text { For coordination purposes } \\
\text { and to exploit synergies, } \\
\text { may be made available }{ }^{3} \\
\text { with (i) the prior consent of } \\
\text { the TA recipient (and the } \\
\text { prior consent of a third } \\
\text { party if the latter provided } \\
\text { information on a } \\
\text { confidential basis) and (ii) } \\
\text { the approval of TA } \\
\text { authoring department }\end{array}$ & $\begin{array}{l}\text { For coordination purposes and } \\
\text { to exploit synergies, may be } \\
\text { made available }{ }^{3} \text { with (i) the prior } \\
\text { consent of the TA recipient (and } \\
\text { the prior consent of a third party } \\
\text { if the latter provided information } \\
\text { on a confidential basis) and (ii) } \\
\text { the approval of TA authoring } \\
\text { department }^{25}\end{array}$ & $\begin{array}{l}\text { Generally not made } \\
\text { publicly available }\end{array}$ \\
\hline $\begin{array}{l}\text { Final TA Advice } \\
\text { (Considered } \\
\text { confidential and may } \\
\text { be made available } \\
\text { only with the consent } \\
\text { of the TA recipient) }\end{array}$ & $\begin{array}{c}\text { Available under } \\
\text { Fund's General } \\
\text { Administrative } \\
\text { Order No.35, } \\
\text { Rev. } 2\end{array}$ & $\begin{array}{l}\text { (a) Executive Director } \\
\text { for the country of the } \\
\text { TA recipient: } \\
\text { Available }^{2} \\
\text { (b) Other Executive } \\
\text { Directors and } \\
\text { members of their } \\
\text { staff: } \\
\text { Available with the } \\
\text { consent of the TA } \\
\text { recipient obtained } \\
\text { on a } 60 \text {-day } \\
\text { nonobjection basis }{ }^{2}\end{array}$ & $\begin{array}{l}\text { Available. } \\
\text { (staff should } \\
\text { encourage the TA } \\
\text { recipient to share this } \\
\text { information with other } \\
\text { agencies or } \\
\text { instrumentalities within } \\
\text { the TA recipient) With } \\
\text { direct TA recipient's } \\
\text { consent Fund staff may } \\
\text { share final TA advice } \\
\text { with other agencies or } \\
\text { instrumentalities of the } \\
\text { member country, non- } \\
\text { member, or } \\
\text { international agency, } \\
\text { as the case may be, on } \\
\text { a non-objection basis. }\end{array}$ & $\begin{array}{l}\text { (a) Final TA advice provided } \\
\text { to Members: } \\
\text { Available }{ }^{23} \text { under the } \\
\text { Fund-Bank Concordat } \\
\text { (unless TA recipient objects } \\
\text { after being consulted by the } \\
\text { authoring TA department) } \\
\text { (b)Final TA advice provided } \\
\text { to Non-members and } \\
\underline{\text { international agencies: }} \\
\text { Available }{ }^{3} \text { with the explicit } \\
\text { consent of the TA recipient. }\end{array}$ & $\begin{array}{l}\text { Available } \text {. }^{23} \text { with the consent of the } \\
\text { TA recipient obtained on a } \\
60 \text {-day non-objection basis }{ }^{6} \text { if } \\
\text { "legitimate interest"7 and the } \\
\text { understanding that the } \\
\text { information should be kept } \\
\text { confidential }^{8} \\
\text { Ex ante irrevocable consent. In } \\
\text { some cases of externally financed } \\
\text { TA, management reserves the } \\
\text { right to approve a request for TA } \\
\text { to be financed by donor(s) only if } \\
\text { the TA recipient provides its ex } \\
\text { ante irrevocable consent to share } \\
\text { all TA reports from that project } \\
\text { with the relevant donor(s). }\end{array}$ & $\begin{array}{l}\text { Staff should } \\
\text { proactively encourage } \\
\text { TA } \\
\text { recipient to explicitly } \\
\text { consent }^{2} \text { to publication } \\
\text { on its own website } \\
\text { and/or on the Fund's } \\
\text { external websites, } \\
\text { pending approval by } \\
\text { the authoring TA } \\
\text { department. } \\
\text { Publication subject to } \\
\text { special policy on } \\
\text { deletions and } \\
\text { corrections prior to } \\
\text { publication. }\end{array}$ \\
\hline
\end{tabular}

\footnotetext{
${ }^{5}$ In consultation with the relevant area department

${ }^{6}$ Which should not prevent the TA recipient from giving its explicit consent to disseminate before the end of the 60 -day period, when there is a need to speed the process of sharing the TA report.

${ }^{7}$ As determined by the authoring TA department in consultation with the relevant are a department. This includes donors financing the project or engaging in related activities with the recipient.

${ }^{8}$ See Appendix C for a model communication containing the standard language to be used. Alternatively, such language could be inserted on a case-by-case basis into a contribution agreement signed with a donor.
} 